$\begin{array}{ll} & \text { Etnográfica } \\ \text { etnográfica } & \text { Revista do Centro em Rede de Investigação em }\end{array}$

Antropologia

vol. 11 (1) | 2007

Vol. $11(1)$

\title{
Contacto, conhecimento e conflito: dinâmicas cultuais e sociais num movimento evangélico cigano na Península Ibérica
}

Contact, knowledge and conflict: social and cultual dynamics in an evangelical gypsy movement in the Iberian Peninsula

\section{Ruy Llera Blanes}

\section{(2) OpenEdition}

\section{Journals}

Electronic version

URL: https://journals.openedition.org/etnografica/1863

DOI: 10.4000/etnografica.1863

ISSN: 2182-2891

\section{Publisher}

Centro em Rede de Investigação em Antropologia

\section{Printed version}

Date of publication: 1 May 2007

Number of pages: $29-54$

ISBN: 0873-6561; E-ISBN 2182-2891

ISSN: 0873-6561

\section{Electronic reference}

Ruy Llera Blanes, "Contacto, conhecimento e conflito: dinâmicas cultuais e sociais num movimento evangélico cigano na Península Ibérica", Etnográfica [Online], vol. 11 (1) | 2007, Online since 25 September 2012, connection on 10 February 2022. URL: http://journals.openedition.org/etnografica/ 1863 ; DOI: https://doi.org/10.4000/etnografica.1863

\section{(ब) $(1) \Theta$}

Etnográfica is licensed under a Creative Commons Attribution-NonCommercial 4.0 International License. 


\section{Contacto, conhecimento e conflito. Dinâmicas cultuais e sociais num movimento evangélico cigano na Península Ibérica}

\section{Ruy Llera Blanes}

Este texto propõe uma análise dos cultos evangélicos da Igreja Filadélfia, um movimento cristão protestante de forte implantação entre os ciganos de Portugal e Espanha. Procurando compreender a importância da prática ritual na experiência religiosa e identitária dos crentes, proponho os conceitos de "contacto", "conhecimento" e "conflito" como mecanismos para explicar como os cultos são local e socialmente implantados na contemporaneidade cigana, ligando ideologia, memória e práticas.

PALAVRAS-CHAVE: ciganos, culto evangélico, ritual, linguagem religiosa, contacto, Península Ibérica.

ENTRE 2002 E 2005, DESENVOLVI TRABALHO DE CAMPO JUNTO DA IGREJA Filadélfia (IF), uma denominação cristã evangélica (de doutrina pentecostal e carismática) com uma implantação importante, progressiva e quase exclusiva entre os ciganos de Portugal e Espanha desde a década de 1960. ${ }^{1}$ Para além de uma evidente intenção de descrição etnográfica, o meu objectivo com esta investigação era o de pensar o cruzamento de práticas e experiências religiosas, dinâmicas musicais e discursos identitários no seio de um movimento

1 Investigação que foi levada a cabo no âmbito da tese Aleluia! Música e Identidade num Movimento Evangélico na Península Ibérica, realizada no Instituto de Ciências Sociais da Universidade de Lisboa e com a orientação de João de Pina Cabral. A mesma incluiu trabalho de campo em Lisboa (entre 2002 e 2004) e Madrid (entre 2004 e 2005) - ver Llera Blanes (2006a). Este artigo reproduz, reformula e discute algum do material ali proposto. Aproveito para agradecer a João de Pina Cabral pelas discussões que fizeram este texto crescer, e ainda aos dois referees anónimos da revista, que o enriqueceram. 
religioso que, apesar da sua abrangência ibérica, se enquadrava num contexto transnacional de evangelização de ciganos iniciado em França nos anos 50 do século XX.

Reformulando, procurava conhecer as particularidades deste movimento religioso protestante, compreender o seu lugar na contemporaneidade dos ciganos e gitanos e explicar o porquê do seu sucesso em contextos nacionais de hegemonia religiosa católica, por um lado, e de suposta antinomia cultural dos ciganos face à ética e moralidade conservadora da fé evangélica (a dita juerga ou inclinação "festiva" versus a ética conservadora) - acrescentando-se a esta equação a centralidade da música enquanto referente identitário, tanto em termos de etnicidade cigana como de prática religiosa. Neste contexto, uma primeira proposta para este artigo seria contribuir - com a descrição etnográfica do seu principal locus de acção, o culto ritual diário -, com elementos para essa compreensão. O culto, nesta perspectiva, seria um "significador social", na medida em que nele convergiam e dele nasciam complexidades sociais e culturais (sentidos de identidade, historicidade, religiosidade, etc.). O que aqui apresento são algumas dessas complexidades.

Nos séculos posteriores aos primeiros ecos da sua presença na Península Ibérica (que data do século XV - ver, por exemplo Liégeois 1989 [1985]; San Román 1997), os ciganos de Portugal e Espanha foram invariavelmente descritos como sendo ora intelectualmente incapazes de formular "sentimentos religiosos superiores" (Coelho 1995 [1892]: 161 e ss.), ora estrategas do fingimento, adoptantes da fé católica por mera conveniência. Este tipo de argumentos era concomitante com a situação histórica dos ciganos nesta região: oriundos de sucessivas vagas migratórias orientais, percorriam a península, instalando-se provisoriamente em acampamentos nas zonas periféricas das urbes ou aldeias, sobrevivendo igualmente à custa de actividades socioeconómicas marginais (compra e venda de cavalos, venda ambulante, ferraria, leitura da sina, etc.). Por razões extensamente debatidas na literatura de e sobre os ciganos, esta presença foi, neste contexto, marcada por políticas mais ou menos oficiais de rejeição e acusação contra as práticas e costumes ciganos (ver San Román 1986; 1997).

A partir da segunda metade do século XX, no entanto, algumas variáveis mudaram drasticamente a situação social dos ciganos: por um lado, verificaram-se importantes reconfigurações ao nível das estruturas económico-políticas de ambos os países: o êxodo rural, a economia de escala, a urbanização e periurbanização e, finalmente, as transições políticas para regimes democráticos, introduziram mudanças irreversíveis nesse "estilo de vida tradicional cigano" - nomeadamente no que se refere a dinâmicas familiares e residenciais e a práticas socioeconómicas. Noutras palavras, os ciganos de Portugal e Espanha passaram, na sua grande maioria, a abandonar o nomadismo e seminomadismo e a residir nos espaços suburbanos e periurbanos, ocupando-se 
com a venda em feiras e mercados (ver Lopes 2006) e a integrar-se em dinâmicas societais de consumo e representação citadinas e plurais (ver San Román 1986; 1997). Neste sentido, este período corresponde a um momento "fracturante" no que diz respeito não só à situação dos ciganos na era "moderna" (no sentido económico, político e sociocultural) como à percepção de si mesmos enquanto colectivo que se habituara a construir-se, por acção ou reacção, como uma alteridade - uma "raça", com usos e costumes diferenciados, minoritária num contexto hegemónico. Essa fractura implicou um confronto dos ciganos com a sua própria "modernidade", obrigando-se a questionar os seus estatutos, tradições, discursos ao nível de redes familiares, práticas residenciais, sistemas de autoridade (ver San Román 1997; Cantón Delgado et al. 2004; Laguna Árias 2005), etc.

Por exemplo, é também neste período que se desenvolvem importantes movimentos de associativismo sociopolítico entre os ciganos a nível internacional - cujo expoente maior será, provavelmente, a União Romani Internacional, que terá uma presença visível na Península Ibérica (será mesmo a maior associação cigana laica em ambos os países). Este associativismo étnico, para além de reivindicar estatutos e direitos na área dos chamados romany rights e de promover uma bandeira, uma língua e uma herança comuns (ver Mayall 2004), também oferecerá uma leitura e memória do passado cigano, ao promover redes associativas étnicas transnacionais e procurar reformular noções históricas de identidade e cultura cigana, recusando aspectos negativos como as acusações de feitiçaria, roubo e mendicidade, e valorizando aspectos positivos como a musicalidade e a autenticidade, genuinidade e autonomia moral.

Ainda, num contexto geográfico onde os ciganos praticavam a religiosidade hegemónica católica, os próprios movimentos de reconfiguração institucional e doutrinal cristã - renovação carismática, novos movimentos eclesiais, etc. (ver, p. ex., Costa 2006) -, surgem aliados a um novo paradigma curial em relação às questões da migração e minorias étnicas: no âmbito de uma "teologia do acolhimento" como método de assistência espiritual aos ciganos, e sob os auspícios do Pontifício Conselho da Pastoral para os Migrantes e os Itinerantes promovido, nos anos 60 e 70 do século XX, por Paulo VI - em resposta ao reconhecimento da "vitalidade cigana" no desenvolvimento de peregrinações multitudinárias como a de Stes-Maries-de-la-Mer e outras (ver Bordigoni 2002; Pasqualino 2002) -, são criados em ambos os países apostolados para a promoção dos ciganos (Obra Nacional da Pastoral dos Ciganos, Asociación Secretariado General Gitano, Asociación Nacional Presencia Gitana, etc.). Estes desenvolvem um importante labor na assistência social dos mesmos, tanto a nível de educação como de inserção nos sistemas nacionais de saúde, identificação, actividades económicas, etc. No entanto, como a própria Igreja reconhece, pouco ou nada é feito no "âmbito espiritual" (Llera Blanes 2006a: cap. II). 
Estes novos movimentos e paradigmas eclesiásticos católicos são, interessantemente, concomitantes com os anos de implantação e crescimento da IF em Espanha e Portugal. Inserida num processo mais amplo de evangelização de ciganos a nível mundial (Mission Evangélique Tsigane Mondiale), iniciado uma década antes por um pastor da Assembleia de Deus francesa, Clément le Cossec (Le Cossec 1985; 2003 [1991]; Williams 1984; 1987), a IF chegou a Portugal por via do proselitismo de pastores ciganos espanhóis, que, nos anos 70, começaram a desenvolver - tal como acontecera uma década antes no contexto espanhol (ver Cantón Delgado et al. 2004) - campanhas de evangelização um pouco por todo o país (Rodrigues e Santos 2004). ${ }^{2}$ Observadores desta realidade em ambos os países discutiram as causas por trás deste fenómeno, que é frequentemente descrito como sendo impactante e transformador na sociedade cigana (Gay y Blasco 2000; 2001; 2002; Cantón Delgado 2001, 2002; Cantón Delgado et al. 2004; Rodrigues e Santos 2004). A implantação e dinâmica envolvente dos locais de culto nos bairros de residência cigana, incorporando e reproduzindo sociabilidades e lógicas familiares e participando na vida local (ver Llera Blanes 2003; 2006); a "acção social" - combate ao alcoolismo e toxicodependência, ajuda aos mais pobres e indigentes, evangelização nas prisões, aconselhamento familiar, etc. - desenvolvida pelas igrejas, preocupadas com uma "política de proximidade" nesses espaços de implantação; o carácter multitudinário da sua acção, apostada na associação e no networking com entidades religiosas transnacionais, o que permite uma maior visibilidade e mediatismo: todos estes elementos se repercutirão nos discursos e percepções, tanto da parte de quem nele participa como de quem o observa, acerca da ideia de "omnipresença" da Igreja enquanto espaço de produção e reprodução de conteúdos relevantes para a compreensão do lugar social de um movimento como a IF entre os ciganos.

Esta omnipresença, no entanto, corresponde a uma minoria numérica em termos de movimento religioso no contexto nacional (português e espanhol). ${ }^{3}$ Mas esta aparente contradição não é senão uma ilusão óptica, motivada pela perspectiva de análise empregue, como procurarei demonstrar daqui em diante, a relevância social de movimentos como a IF é verificada pelo seu impacto local em contextos de complexidade urbana que escapam a perspectivas espáciotemporais mais abrangentes (nacionalistas, regionalistas, epocais, etc.), estruturando percepções, discursos e práticas situadas. Perante a ausência de dados estatísticos homogéneos e fiáveis acerca de conversões de ciganos ao movimento

2 Este movimento é também contextualizado pelo enquadramento jurídico progressivamente aberto à constatação da pluralidade e direito à liberdade de crença e prática religiosa em Portugal e Espanha, acelerado com a transição política para regimes democráticos.

3 Em Portugal e Espanha, as religiões não católicas - onde o protestantismo e a IF se incluem - nunca superaram, ao longo do século XX, a percentagem de 2,3 a 2,5\% das respectivas populações (Vilaça 2006: 160; Swick 1999). 
evangélico (ver Méndez Lópes 2006), esta posição também pode ser suportada pela verificação empírica: hoje, é difícil encontrar já bairros de alojamento de famílias ciganas onde não esteja instalada uma igreja "Filadélfia".

\section{CULTO}

Tendo estas questões em conta, o meu trabalho de campo teve como eixo central de análise os principais momentos de acção e interacção religiosa dos crentes da IF - ou, noutras palavras, os cultos. Os cultos, na IF, têm uma periodicidade quase diária: por norma, têm lugar seis dias por semana num horário pós-laboral, tanto em Espanha como em Portugal. No entanto, para os crentes e "servos" (pessoas que trabalham em prol da Igreja), a palavra "culto" tem um significado mais abrangente e ambivalente: é frequente ouvi-los falar de "culto" tanto para designar a prática litúrgica diária de louvor ("eu faço culto"), como para designar o local onde esta se desenrola ("eu vou ao culto"), como ainda a denominação religiosa em geral ("eu pertenço ao culto").

Esta polissemia é particularmente sugestiva. Em primeiro lugar, porque denuncia a centralidade do culto na experiência religiosa dos crentes da IF e, em particular, do referido "culto diário" na estruturação das práticas colectivas dos seus integrantes enquanto congregação em cada igreja. Em segundo lugar, porque nos permite invocar a importância da vertente experiencial, performativa e participativa na constituição de um espaço colectivo de crença e acção: "eu sou crente na medida em que presto culto". E também porque, como defenderei ao longo deste texto, os processos de "designação linguística" serão indicadores da importância da "linguagem religiosa" na construção da experiência religiosa e, em particular, da prática ritual. A condição de crença é, neste sentido, definida através da participação cultual, porque será através dela que o crente forma conceitos, concepções, visões e estilos de "prática" sócio-religiosa: ao participar nos cultos, o crente deparar-se-á com éticas, visões do mundo, consciências históricas e corporalidades que confrontará com as suas próprias categorias individuais.

Nesta linha, proponho como principal argumento para este artigo a noção de que, na medida em que a "experiência religiosa" é mediada pela participação cultual, ela é definida por aquilo a que chamo de políticas de "contacto" (e interacção), "conhecimento" (e reconhecimento) e "conflito" (ou discrepância). De contacto, porque o acto cultual é simultaneamente um acto de linguagem e comunicação através da participação e interacção entre os crentes. De conhecimento, porque essas comunicação e participação entre os crentes incorporam, reproduzem e produzem corpos de ideologia e prática (lógicas, argumentações, formas de fazer). Finalmente, de conflito, porque esses corpos não são homogéneos: é no debate e na discrepância que se reafirmam, renovam e reconstroem. 
A noção de contacto é, nesta proposta, crucial para entendermos como as dinâmicas de representação e significação se entrecruzam com os conteúdos das práticas rituais e cultuais observadas: entendido como um espaço de verificação de "modos de conhecimento" (Comaroff e Comaroff 1991; Pels 1999), tanto a nível explícito (oral, representativo) como a nível implícito (físico, material, táctil, "mudo" - Taussig 1991; Pels 1999: 23 e ss.), o "contacto" é simultaneamente uma epistemologia e uma estética aplicável a contextos de acção e participação. Neste sentido, é também um espaço de geração e negociação de sentidos, um espaço de aprendizagem e intenção. E é nessa negociação que se alojam o conflito, a discrepância, a contradição, a dialéctica que caracterizam os "ciclos de desenvolvimento" da vida social (Turner 1995 [1969]).

Assim, e voltando ao domínio do empírico, a centralidade do culto é verificada, essencialmente, pela sua acção "estruturante" nas vidas dos seus frequentadores e respectivos familiares, tanto em termos de contribuição para a organização social e profissional quotidiana (o culto é, como referimos acima, diário), como de contribuição para o estabelecimento de relações contínuas e duradouras entre os participantes (que respeitam, na sua maioria, essa frequência diária).

No culto, é possível distinguir três momentos chave neste processo: durante a hora e meia ou duas de duração do culto, os crentes participam em três ordens de acção distinguíveis: a "adoração", a "oração" e, por último, a "palavra" (ou pregação). Estes três momentos, explicitamente definidos pelos participantes enquanto tal, compõem os actos essenciais e constantes dos cultos, mas não são necessariamente levados a cabo da mesma maneira: os seus tempos de duração são variáveis e, frequentemente, sobrepõem-se uns aos outros.

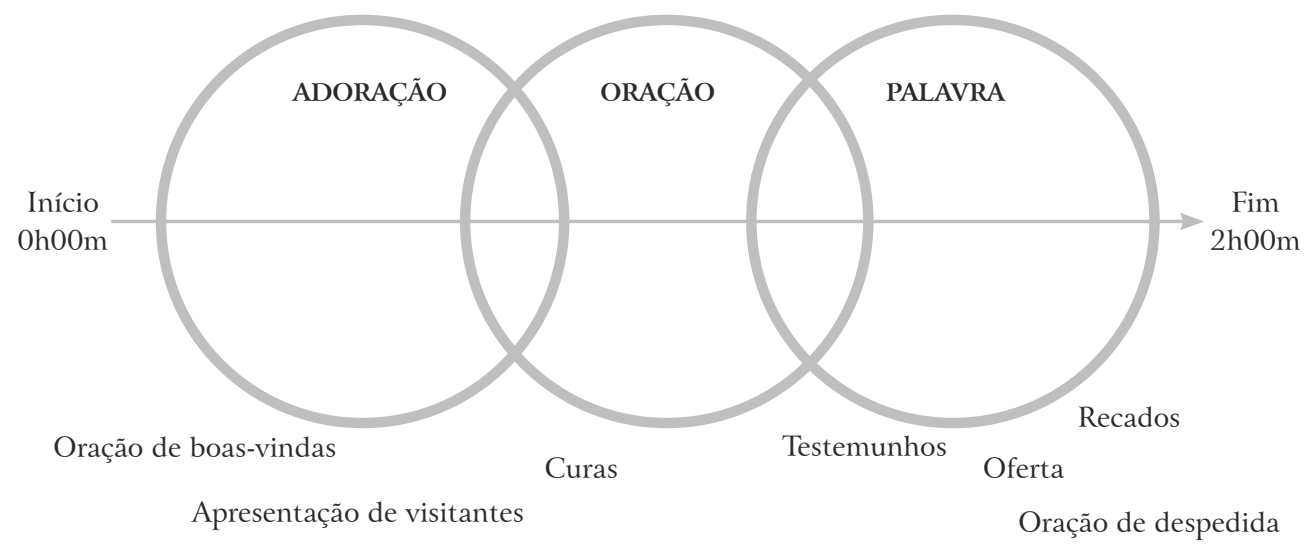

Figura I - Culto na Igreja Filadélfia (esquema). 
Nesta perspectiva, não é, no entanto, possível defender a existência de uma prática cultual unívoca e homogénea aprioristicamente estruturada no conjunto dos locais de culto da IF. Em primeiro lugar, porque a própria condição doutrinal e litúrgica da IF, enquanto movimento protestante pentecostal carismático, não prevê essa homogeneidade: nele, a crença é realizada a partir da ideia da possibilidade de contacto imediato entre o crente e o divino através da manifestação do Espírito Santo no crente, que é deste modo baptizado e imbuído do poder dos dons (glossolalia, visão, cura, etc.), ou seja, do carisma. Neste contexto, como veremos mais adiante, o acto cultual é percepcionado como sendo mediado ou guiado pela "vontade de Deus".

Por outro lado, esta denominação promove uma estrutura organizativa autonomizada e não hierarquizada relativamente às suas igrejas, o que faz com que cada local de culto se defina e estruture quase exclusivamente a partir da sua composição humana e recursos financeiros: no entendimento de que os crentes também são participantes activos no culto, as suas particularidades enquanto grupo de pessoas ou comunidade afectarão o desenrolar concreto do acto cultual, desde a frequência de realização à duração e às configurações, componente musical, etc. - elementos que são negociados entre pastores e crentes de igreja para igreja.

Por último, a própria participação diária sujeita-se a uma dinâmica de flutuação e variabilidade que resulta dos imponderáveis do quotidiano. Neste contexto, podemos enquadrar a ideia de que há diferentes motivações, níveis e registos de participação nos cultos - os servos, os obreiros, os membros do grupo de louvor (coro musical), os crentes indefectíveis, os ocasionais, os filhos e netos... -, tantos quantos os crentes presentes nos mesmos. No fundo, uma constatação que define a própria participação individual em contextos de interacção e performatização colectiva (ver Valverde 2000).

No entanto, mesmo tendo em conta esta variabilidade, os crentes da IF participam no culto com um objectivo comum - o de "fazer culto a Deus", orando, cantando e procurando a sua presença, o seu contacto, a sua manifestação - ao mesmo tempo que promulgam diferentes modos de participação no mesmo com maior ou menor envolvência física e mental - diferenças de aproximação e aceitação que são mediadas por experiências individualizadas e interacções colectivas, e condicionalismos derivados de questões etárias, de género, condição socioeconómica, etc. Através da observação empírica, apercebemo-nos - como veremos mais adiante - de discursos e interpretações diferenciados acerca do que é ou deve ser a prática cultual, mais ou menos instituídos em "ideologias" ou correntes de pensamento. Nesta linha, o acto cultual desfruta de uma enorme centralidade na IF: enquanto cerimónia ritualizada, congregadora dos seus crentes, “o culto" é simultaneamente receptáculo e produtor de doutrina teológica, experiência religiosa e visão do mundo. Como veremos, o acto cultual é configurador do tipo de experiência religiosa procurado pelos 
crentes ciganos, ao mediar a experiência carismática dos "dons" ou "carismas": os dons da visão (ou profecia), do conhecimento, da cura e da glossolalia (falar em línguas) ${ }^{4}$ são propiciados, segundo a crença pentecostal e carismática, pela invasão do crente pelo Espírito Santo; o espaço e o tempo dos cultos são espaços assumidos de tentativa de recebimento dessa invasão ou, em alternativa, de partilha das experiências da mesma.

Assim, de acordo com esta perspectiva, o culto não é tanto um "encadeamento mecânico de acções antecipadamente reguladas" - ideia frequentemente associada à prática ritual (Bourdieu 2002: 232; ver também Asad 1993: 55 e ss.) - mas sim um espaço (e processo) de interacção e produção social. Como discutiremos mais adiante, mais do que uma "representação" ou acto simbólico ou formalizado de uma liturgia, ou de um "drama social" no sentido turneriano (Turner 1996 [1957]), propomos aqui uma aproximação ao culto enquanto ritual de participação e produção de práticas: para além de reproduzir "ortodoxias" e "ortopraxias" - ideologias, categorias e práticas consensualizadas, mais ou menos hegemonicamente, como sendo "correctas" (ver Bell 1997) - os cultos constituem, pelo seu carácter diário, contextos processuais de constituição identitária (tanto a nível individual como colectivo) através da "prática social", isto é, produzem conhecimentos, significados e categorias através da participação relacional entre os seus agentes. Recordamos aqui a noção de Jean Lave e Etienne Wenger de "comunidade de práticas", definida como " $a$ set of relations among persons, activity, and world, over time (...) an intrinsic condition for the existence of knowledge" (1991: 98). Também proponho uma interpretação dinâmica e processual da "teoria da prática" (Bourdieu 2002), olhando para os cultos religiosos como resultantes, deste ponto de vista, de uma dialéctica entre hábitos, disposições, ideias, percepções e acções que, por sua vez, são geradoras de novos moldes para a prática. Neste sentido, interpreto a prática ritual como uma forma de acção e participação - necessariamente complexa, heterogénea e diversificada, mas motivada por uma intenção e voluntariedade colectiva - através de dinâmicas comunicacionais e interaccionais. Acção e participação são, em si, produtoras de "socialidades cristãs ciganas", na medida em que incorporam, reproduzem, actualizam e produzem sentidos, experiências, memórias e visões do mundo concretas para as pessoas que participam nos cultos. Argumentarei igualmente que a "comunicação ritual" (pace Bloch 1989 [1979]) é multifacetada e, através de actos como o canto, a oração, a predicação, a escuta, manipula diferentes registos de semânticas que são transportadas de e para fora da esfera do culto. Maurice Bloch, apesar de conferir a esta comunicação ritual um lugar externo ao quotidiano e ao ordinary, invoca a sua

4 "Falar em línguas" (hablar en lenguas) é a expressão que designa o dom da glossolalia, a capacidade de falar em línguas desconhecidas quando se está em oração. Os primeiros a receber estes dons foram os apóstolos (ver Actos 2: 1-13). 
importância na instauração de historicidade, autoridade e ordem (1986; ver também Lambek 2002). No argumento aqui apresentado, a dinâmica cultual característica da IF e da religiosidade evangélica pentecostal serve em simultâneo os propósitos de sociabilidade quotidiana e de institucionalização de autoridade, por exemplo ao configurar bases bíblicas (ou de fundo bíblico) para as lógicas de relacionamento ali desenvolvidas, atribuir prestígio social àquele que se dedica à "obra" da IF, etc.

É neste contexto que, no meu trabalho de campo nos locais de culto, identifiquei aquilo que apelidei de dinâmicas e políticas de contacto, conhecimento e conflito. Nas linhas que se seguem, pretendo exemplificá-las ao integrá-las na descrição da prática ritual dos cultos da IF. Para tal, tomarei exemplos dos diferentes momentos que pontuam os cultos, recolhidos tanto em Lisboa como em Madrid.

\section{CONTACTO}

Os locais de culto da IF não são, por norma, edifícios monumentalizados ou monumentalizáveis. São, na sua maioria, garagens, lojas, caves, casas pré-fabricadas, etc., instaladas nos bairros sociais dos subúrbios de cidades como Madrid e Lisboa, que um grupo de crentes conseguiu alugar para formar uma "igreja". Estes espaços encontram-se, regra geral, dentro do próprio espaço de residência dos crentes, inserindo-se nas dinâmicas de quotidiano locais.

As igrejas da IF nascem a partir de uma lógica de "localidade"; os evangelizadores realizam um trabalho específico de proselitismo num bairro ou área concreta que considerem necessitada a este nível. Se o trabalho for bem sucedido, é criado um "campo" com o grupo de fiéis entretanto conversos, que começarão a fazer cultos nas respectivas casas. Uma vez criado um grupo de tamanho suficiente, procurar-se-á, finalmente, um espaço constituível como "igreja” - que assumirá a configuração resultada da contribuição dos próprios crentes.

Neste contexto, tal como pude observar em Lisboa e Madrid, a frequentação aos cultos é composta por redes de grupos familiares e vizinhos - que se constituem igualmente como espaços privilegiados de evangelização e conversão (ver Llera Blanes 2003; 2006b) -, integrando os hábitos cultuais nas suas actividades diárias de trabalho, lazer e sociabilidade.

Nos dois contextos, os distintos grupos e famílias ciganos - já de si extremamente heterogéneos no que se refere a proveniência imediata, grupo familiar, estatuto sócio-económico, níveis de ensino e práticas de consumo e produção cultural (ver Llera Blanes 2006a) - habitam e vivem ambas as cidades de forma específica: concentrando-se na sua maioria em bairros suburbanos periféricos (em muitos casos, inseridos em políticas de realojamento), dedicam-se na sua 
grande maioria à venda nos mercados e feiras locais. ${ }^{5}$ Estas particularidades, por sua vez, configuram redes de sociabilidades locais anexadas a cada local de culto.

Como sugeri anteriormente, um dos factores de sucesso na expansão e implantação da IF entre os ciganos relacionava-se com as referidas "políticas de proximidade" promovidas pela denominação: os espaços de culto são, por assim dizer, "espaços de vivência", onde os crentes convivem e interagem, participando na decoração, manutenção, limpeza e melhoramento do espaço comum. Do mesmo modo, as igrejas dependem em exclusivo da contribuição financeira dos seus crentes: é com as "ofertas" ou dízimos (em espanhol, diezmos) dos frequentadores dos cultos que se obtém financiamento para aquisição de materiais, obras, actividades, etc. Finalmente, a esfera de acção das igrejas extravasa o espaço de culto, inserindo-se na malha urbana em redor: as visitas a outras igrejas nos dias de folga, o "trabalho social" - que inclui assistência social (roupas, alimentação) a indigentes ou a evangelização nas prisões, por exemplo -, as "escolas de jovens" (sessões informais de leitura e estudo bíblico para os filhos e netos dos crentes) ou mesmo o trabalho de recuperação de alcoólicos ou toxicodependentes, são disso ilustração.

É neste sentido que os cultos aparecem como pontos de encontro, contacto e interacção: aproximadamente meia hora antes do início do culto, grupos de pessoas começam a agrupar-se nos espaços interiores e limítrofes do local, ora montando e afinando instrumentos e microfones (no caso dos integrantes do coro musical da igreja), ora alinhando cadeiras e bancos, ora simplesmente pondo a conversa em dia.

À chegada dos "obreiros" (pastores, predicadores, evangelistas, etc.) à igreja, procura-se instalar uma ordem e silêncio que permitam dar início ao culto. O primeiro predicador da noite a pegar ao microfone começa a dar as boas-vindas e a pedir às pessoas para se sentarem e começarem a observar o culto. Anunciará o "programa" do culto e recordará a razão pela qual se encontram todos ali.

Vamos cantar para Jesus com alegria, porque Deus quer que nós, o seu povo, se apresente diante dele com alegria, Ámen, porque nós temos motivos para estar alegres. Não concordam comigo, igreja? [Ámen!] (...) Jesus venceu Satanás lá na cruz do Calvário, e Ele nos deu a vitória a nós. Por isso, nós, aleluia, também já vencemos o diabo, e a vitória é nossa, em nome

5 Refiro-me aqui a bairros e municipalidades como a Brandoa, Galinheiras (Lisboa), Apelação, Quinta da Fonte, São Sebastião de Guerreiros (Loures), Bela Vista (Setúbal), etc. - em Portugal - e Carabanchel, Hortaleza, Getafe, Leganés, Villaverde, Caño Roto, Orcasitas (Madrid), etc. - em Espanha - lugares que frequentei durante o meu trabalho de campo. Em Madrid, no entanto, essa heterogeneidade era mais evidente. Por exemplo, um grupo com quem trabalhei - e que participa parcialmente na descrição etnográfica aqui reproduzida - habitava um bairro central da cidade e trabalhava em profissões outras que não a venda informal (música, etc.). 
de Jesus. Por isso vamos louvar a Deus com alegria, porque Jesus habita no meio do louvor, Glória a Deus. (30-10-2003, Lisboa)

A voz amplificada do orador começa pouco a pouco a impor-se ao burburinho conversacional. Os frequentadores vão procurando os seus assentos e os mais pequenos vão, a pouco e pouco, reduzindo as suas correrias e brincadeiras A afinação dos instrumentos transforma-se gradualmente num compasso rítmico, definido pelo líder do coro, que introduzirá a guitarra, o teclado e outros elementos percussivos ou melódicos e, finalmente, as vozes do coro feminino. Simultaneamente, o público, que se posiciona nos seus lugares, sentado ou em pé, começa a acompanhar a canção com palmas e canto em coro.

Estes cânticos - executados em estilos de flamenco, essencialmente na rumba - são frequentemente apelidados de "cânticos de júbilo" (em espanhol, cánticos de alabanza), peças musicais que têm como objectivo a "exaltação e glorificação de Deus" através de expressões de "adoração". Do ponto de vista doutrinal, o canto, e em particular o cântico de júbilo, é entendido como um método de "adoração", ou seja, de culto a Deus - respeitando a própria etimologia do termo, do latim ad orare. Neste sentido, na gramática comunicacional do culto, o cântico promove uma experiência que se pretende ser de "contacto" com o Espírito Santo através da sua adoração exaltada, alegre; neste sentido, é perceptível como os crentes, sem ter necessariamente o raciocínio teológico em mente, encaram o "louvor" como um mecanismo de predisposição física e emocional para o acto da adoração. Esta exaltação é expressa explicitamente nas letras dos cânticos, formulados na primeira pessoa e no discurso directo. Por exemplo:

Por isso eu quero abraçar-te

Por isso eu quero sentir-te

Por isso eu quero adorar-te.

$$
\begin{gathered}
\text { Santo, Santo, Santo, Santo } \\
\text { Santo és, Deus } \\
\text { És Santo. }
\end{gathered}
$$

Este discurso directo é característico daquilo que poderíamos definir como "representações comunicacionais" de ideologias e relações sociais (ver Keane 1997): o "poder mágico" das palavras veiculadas deriva da forma e do contexto ritual onde são produzidas (Tambiah 1968). Neste sentido, as lyrics aqui ilustradas são produzidas em função da sua aplicação ritual, incorporando tanto componentes rítmicas e melódicas (tendo em vista a sua dimensão hínica) como componentes de conteúdo (tendo em vista a veiculação de uma ideia ou experiência). São, neste contexto, "economias de representação", porquanto 
são produto da combinação entre pessoas, objectos, relações, significados e valores (Keane 2002; Meyer 2004). ${ }^{6}$

Estes momentos de adoração podem estender-se ao longo de até trinta minutos. Gradualmente, porém, o seu final será gerido à medida que o predicador da noite (que não é necessariamente o pastor da igreja) vai dando conta aos músicos, com gestos, da sua intenção de prosseguir com o momento seguinte: a oração. As luzes são desligadas, e o predicador interpela os presentes a fecharem os olhos e predisporem-se para a oração. Solicita a um crente para que ele faça, em voz alta, uma oração de "apresentação do culto", isto é, de declaração das intenções dos presentes e de invocação ou chamamento para a presença de Deus no culto:

Senhor, Deus da Glória, Senhor das nossas vidas, eu quero dar-te graças Senhor. Tu estás no nosso meio, Senhor, para abençoar-nos Senhor, e porque nos permites um dia mais, Senhor, estarmos reunidos para louvar o teu nome Senhor, pois tu és rei, Senhor das nossas vidas. Nós te exaltamos Senhor; este, Senhor, é o propósito, é louvar-te e engrandecer-te. Pai, tu és digno de toda a glória e de todo o louvor, pois tu nos deste a salvação eterna Senhor, tu nos deste a conhecer, Senhor, a vida eterna, Pai, a salvação da nossa alma, Pai. Abençoa a tua igreja, o teu povo nesta noite, que possamos estar dispostos para adorar-te, Espírito Santo, Senhor, a nossa vida, Senhor, está na tua vontade Senhor. (...) Abençoa os servos, Senhor, o coro que canta para ti, toda a gente neste lugar. Jesus abençoa. Ámen. (25-04-2003, Lisboa)

$\mathrm{Na}$ escuridão, ao som de cânticos mais melancólicos e emocionais, percebemos como os restantes crentes começam, individualmente, também eles a orar. Observamos nas expressões faciais e disposições físicas dos crentes como estes procuram um determinado estado mental e físico, propiciado pela experiência do "contacto" com o divino. Alguns sentam-se e fecham os olhos; outros abrem os braços; outros, ainda, ajoelham-se, colocando os cotovelos nas cadeiras e as mãos na cara. Neste contexto, as diferentes posturas adoptadas pelos crentes nos momentos de oração reflectem a percepção de que a "oração" é uma forma de experiência de contacto divino: os braços abertos, por exemplo, denotam uma intenção de "recebimento corporal" do Espírito Santo. Ouvimos também alguns crentes a gemer e a falar em línguas.

Todas estas manifestações corporais reproduzem a noção de que os crentes estão a receber aquilo a que chamam de maná, isto é, o "alimento de Deus", que

6 Meyer propõe a noção de "estilo" como mecanismo de criação de distinção entre e, simultaneamente, alinhamento de formas expressivas através de registos comunicacionais diversos - que incluirão discursos, filmes, teatro, pintura, música, etc. (2004: 94). 


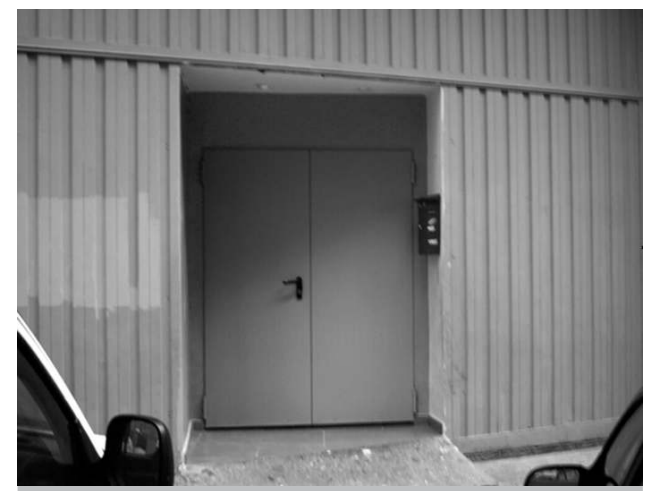

Figura 2 - Local de culto da Igreja Filadélfia, Madrid. (Fotografia do autor)
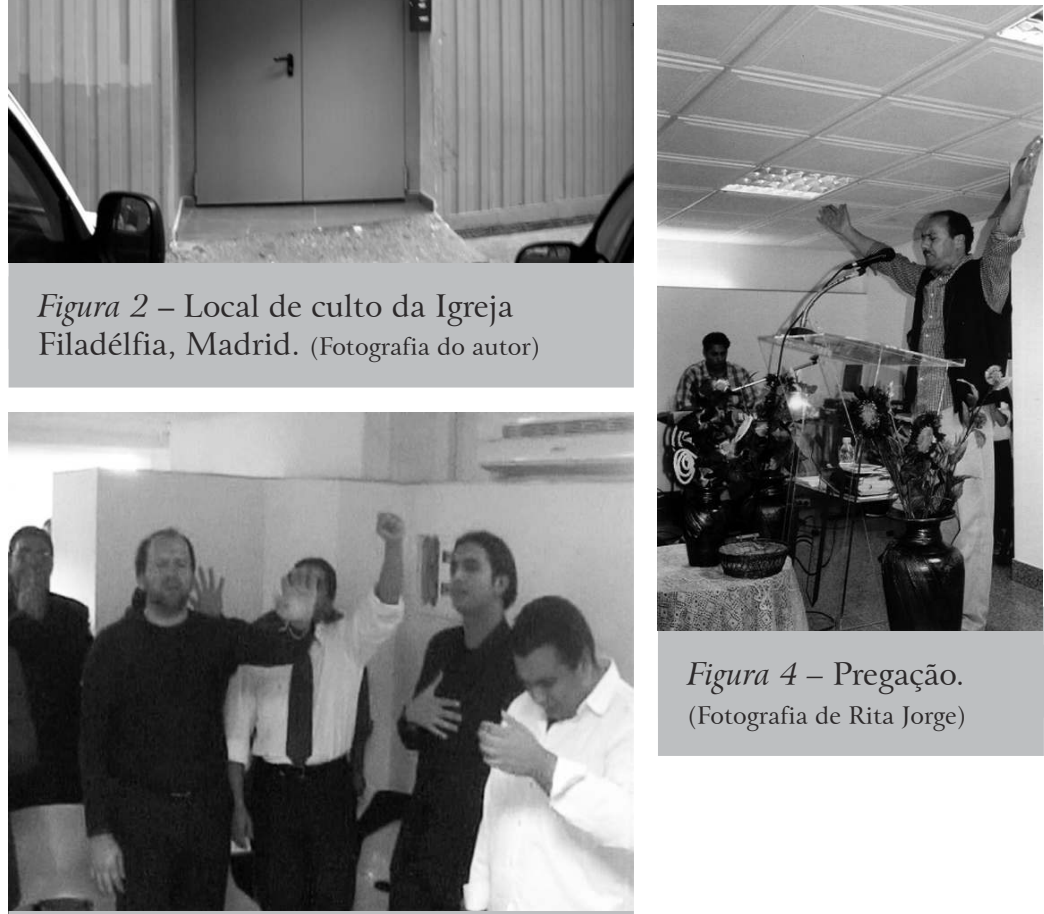

Figura 4 - Pregação. (Fotografia de Rita Jorge)

Figura 3 - Oração. (Fotografia do autor)

nos contextos pentecostais carismáticos é traduzido nos distintos dons que se acredita serem atribuídos na experiência do Espírito Santo. ${ }^{7}$ No entanto, talvez a expressão émica que melhor defina a experiência do contacto e o objectivo último do culto seja a de shekinah, ou seja, a "presença de Deus". Shekinah, de origem hebreia, é frequentemente referida por crentes e oradores como algo que se cultiva através do culto, uma manifestação ou revelação ("contacto") propiciada pela adoração, que produz a "irradiação," a "glória de Deus". ${ }^{8}$

7 O conceito de "maná" aparece na Bíblia, no livro Êxodo. Era o alimento que Deus dera ao povo de Israel aquando da sua fuga do Egipto e posterior travessia do deserto (ver Exodo 1-14). Neste sentido, é empregue nos meios evangélicos e pentecostais como símbolo dos "dons" atribuídos pela experiência carismática, ou seja, a experiência do Espírito Santo.

8 O conceito de shekinah é por vezes confundido com o do Espírito Santo, enquanto manifestação de Deus na terra. No entanto, apesar dos significados semelhantes, estes divergem na medida em que a shekinah é uma manifestação visível, enquanto que o Espírito Santo é uma entidade em si. [continua] 
A oração é também um momento de "intercessão" por aqueles que estão a sofrer com doenças e/ou problemas pessoais: é nestes momentos que os crentes em pior estado físico e anímico se aproximam junto do pastor e pedem a "intercessão” ou cura por imposição de mãos. A intercessão é um conceito importante para a doutrina da IF, na medida em que representa um acto concreto de comunicação entre o crente e Deus: aquele pede a este, através de uma oração, uma "intervenção" em favor de uma pessoa ou grupo concreto. Este acto implica um sentido de experiência religiosa que passa pela percepção de que a crença é, também, um acto de reciprocidade no seio do grupo (ver, por exemplo, l Timóteo 2: 1).

Ainda, o trabalho do pastor é complementado pela ajuda dos restantes crentes, que orarão "em favor de" os crentes mais necessitados. É nesta dinâmica de emotividade propiciada pelo ambiente de oração, marcado pela escuridão (que fomenta uma maior percepção auditiva) e por uma acústica invadida por lamentos, choros, incitações, etc., que se produzem frequentemente episódios em que um crente ou obreiro é "tocado pelo Espírito Santo", recebendo o dom da visão ou cura, ou apenas desata num choro convulsivo, num sentimento de expiação dos seus problemas.

Neste contexto, apercebemo-nos de como estamos perante aquilo a que Bennetta Jules-Rosette chama de managed event in ceremony (Jules-Rosette 1975: 99 e ss.), isto é, um acto litúrgico onde, ao contrário do que sucede noutros contextos religiosos e em particular católicos, não há uma imposição apriorística do método e duração da execução ritual. O argumento do acto cultual é construído de forma relacional, resultando da interacção (no sentido de ser uma negociação implícita) imediata dos presentes. Em parte, isto deve-se uma vez mais à experiência religiosa carismática e pentecostal promovida pela doutrina da IF: na medida em que a experiência do divino é individualizada e determinada pela vontade de Deus (e não dos homens), não pode haver uma determinação rígida da mesma; os cultos são, em última instância, determinados por Deus. Falaríamos, então, de um processo de "internalização" da palavra (discurso) e da Palavra (Bíblia), tal como é proposto por Simon Coleman (2000: 127 e ss.): a instauração de mecanismos e práticas que procuram incorporar, inscrever no corpo dos crentes em oração uma concepção determinada de crença. Essa concepção, por sua vez, é marcada pela noção de "contacto" - com o divino e com a própria comunidade, no sentido durkheimiano (2002 [1912]).

\section{CONHECIMENTO}

O final da oração é marcado pelo acendimento das luzes e pelo abandono do palco por parte dos músicos: é chegado o terceiro momento, o da "palavra". 
Neste ponto, o púlpito é ocupado por oradores, pessoas que irão oferecer leituras, apresentações e ensinamentos. Esta secção é relativamente plástica, no sentido em que é ocupada por acontecimentos vários: sermões, testemunhos, saudações de visitantes convidados, apresentações musicais, recitais, etc. No entanto, talvez os dois momentos mais marcantes (porque invariáveis) sejam os testemunhos e os sermões.

Os testemunhos - narrações públicas, na primeira pessoa do singular, de episódios concretos - costumam invocar acontecimentos na vida dos crentes que descrevem as suas experiências religiosas e de crença; neste contexto, muitos testemunhos incorporam tanto narrativas de perdição e salvação como experiências de contacto divino - acontecimentos que reforçam a própria condição de fé dos crentes.

Por exemplo, em Maio de 2003, uma IF de Lisboa recebeu a visita de um predicador brasileiro que se encontrava em viagem pela Europa para partilhar o seu testemunho, e considerado pelos obreiros da igreja como sendo especialmente "poderoso". Tratava-se de uma história pessoal carregada de dramatismo: oriundo de uma família economicamente miserável (o seu pai era alcoólico e desempregado), ele começou a frequentar uma Assembleia de Deus na Baía, onde trabalhava como servo. Apesar de se manter pobre, o agora predicador era ambicioso e decidira enveredar, ainda jovem, por uma carreira de boxeur. Rapidamente começou a ter sucesso; no entanto, a sua ascensão profissional e económica fora feita graças a um pacto que celebrara com o diabo através da macumba. Era, simultaneamente, boxeur e gangster. Nesses tempos, conta, ele era tão "ruim" que nem podia entrar pela porta de uma igreja: "o diabo não entrava em mim, eu é que entrava nele!”. As crianças tinham medo dele, as pessoas nem o olhavam nos olhos; no entanto, cada vez era mais rico. Os seus antigos companheiros de igreja choravam a sua perda. No entanto, Deus revelou a um deles que ele ainda seria salvo e que, um dia, acabaria por pastorear uma igreja. O diabo, ao perceber que iria perder o seu "aliado", decidiu que o predicador deveria morrer. Capturado no meio de uma luta de gangs dentro de um comboio no Rio de Janeiro, estava prestes a ser executado. Quando chegou a sua vez, orou a Deus, pedindo-lhe: "Deus, se tu existes, deixa-me viver". Nesse momento, o comboio descarrila e o predicador, ao contrário dos seus inimigos, sobrevive.

Os "testemunhos" são, neste sentido, percebidos como "provas do poder divino" e enquadram-se na experiência carismática dos dons, no sentido em que relatam, quase invariavelmente, acontecimentos de "intervenção divina" e mediação da miraculosidade. ${ }^{9}$ Acabam por ser, neste contexto, "estímulos

9 Neste ponto, convém recordar que estes testemunhos não se resumem em exclusivo às chamadas narrativas de conversão evangélicas - tão exploradas nas ciências sociais (ver, para um debate sobre as mesmas, Stromberg 1993; Csordas 1997; Crapanzano 2000; Mafra 2002a; 2002b; Harding 2000) - apesar da centralidade destas nos actos cultuais. Os "testemunhos", aqui, remetem mais para a ideia de "provas do poder de Deus" que podem ou não incorporar experiências de conversão. 
de fé", isto é, narrativas que reforçam, em contextos rituais, as motivações de crença que promovem o encontro diário e a liturgia: como "elementos de acção", as palavras constituem actos comunicacionais inerentes e constitutivos do próprio acto ritual (ver Austin 2005 [1962]; Tambiah 1968; Mafra 2002b). A integração do acto testemunhal no contexto do culto é, neste sentido, geradora de noções de crença através da partilha de experiências que fornecem instrumentos conceptuais e narrativos, que os restantes crentes incorporarão, como práticas, na sua memória e experiência religiosa (ver Whitehouse 2004). Como dizia o predicador brasileiro acima citado, "quando o milagre acontece, o povo vem".

O outro momento particularmente central nesta dinâmica é o sermão - o momento mais "calmo" e corporalmente restrito dos cultos. Este parte invariavelmente da leitura de uma passagem bíblica, que será analisada e extrapolada numa ideia ou mensagem que o predicador pretende partilhar com a audiência. Essa mensagem é frequentemente invocada como uma "palavra divina", isto é, como uma oratória inspirada ou oferecida por Deus e que o predicador, enquanto transmissor, partilhará. Neste contexto, os sermões incorporam uma mensagem com componentes de reflexão ético-moral, versando, com um estilo simultaneamente pedagógico e performado, sobre "a condição de crente" na IF.

Quero falar-vos da palavra do Senhor, que está no livro de Levítico, capítulo 8. [...] versículo 24, diz assim: "Moisés fez chegar também os filhos de Abraão, e pôs daquele sangue sobre a ponta da orelha direita deles, e sobre o polegar da sua mão direita, e sobre o polegar do seu pé direito; e espargiu o sangue sobre o altar em redor." Quantos podem dizer ámen? [A assistência responde com um "ámen"]. Senhor Jesus, hoje apresentamo-nos perante Ti, é a Tua palavra que tem todo o poder, toda a glória, toda a honra, todo o império, todo o senhorio, tudo é despido perante ela, Senhor. Não há nada que possa permanecer encoberto. Nesta hora, apresentamo-nos ao poder e amparo da Tua palavra. Porque sabemos que ela não volta para Ti vazia, antes faz bem tudo aquilo para o que a mandaste e é prosperada em tudo aquilo para o que a enviaste. Em nome de Jesus de Nazaré oramos, porque, através desta palavra, aquele que caiu se levanta, o débil se fortalece, o doente se cura, aquele que está desanimado se anima [grita], abrem-se novas portas, porque sabemos que a Tua palavra, sim, é poderosa! Uma palavra Tua tem o poder de nos levantar, porque nesta tarde queremos fechar esta oração com este aplauso para a Tua palavra! Aleluia! [Aplausos] (20-04-2005, Madrid)

Esta leitura respeita uma retórica explícita de extrapolação de uma passagem bíblica - é, em simultâneo, uma proposta de exegese e interpretação, ou seja, de oferta de um "estilo de leitura" e de um "método de entendimento". No que se refere à exegese, o acto de "pegar" (no sentido de possuir, utilizar, ler) numa Bíblia, para um crente, implica uma panóplia de escolhas que o tornam num 
acto de significação complexa. A Bíblia, para além de objecto de posse, uso e também intercâmbio (exchange), incorpora igualmente um peso histórico-social que permite aos crentes nela depositar os fundamentos da sua condição de crença e da sua própria visão do mundo, propondo, em consequência, uma noção concreta de individualidade que não corresponde aos arquétipos da sociedade moderna e laica. ${ }^{10}$ Este acto de depositar não só implica a criação de um sentido de pessoa e história como também de um "elo transcendental", no sentido em que atribui um carácter histórico à Bíblia.

Nesta linha, o acto do sermão incorpora políticas de conhecimento, no sentido em que é entendido como um momento de ensinamento e aprendizagem de um recurso específico de autoridade intelectual, social e histórica: ao recorrer ao objecto textual da Bíblia para promulgar propostas comportamentais e visões do mundo ("comentar"), o predicador oferece aos crentes e ouvintes, partilha com eles um entendimento concreto (literalista, conservador) de história, memória e autoridade moral.

Moisés chama os sacerdotes e lhes põe sangue no lóbulo da orelha directa. O que significa isto? O nosso ouvido tem de estar sob a influência do sangue. Temos de ter muito cuidado com aquilo que ouvimos [ouve-se um "ámen" colectivo]. O ouvido é um dos membros mais importantes que executa um dos sentidos mais importantes que há no corpo humano. Satanás sabe que se ganhar o nosso ouvido terá ganho o nosso corpo. [...] Vocês sabem como é que se produziu a primeira tentação e a primeira queda na terra? Precisamente porque uma mulher deu ouvidos às palavras de uma serpente. Entrou em conversação com ela, ouviu o que ela the disse. Se Eva lhe tivesse dito: "eu não te posso ouvir, aquilo que me dizes está totalmente em contra daquilo que Deus me disse"... O diabo sabia que se chegava a ter o seu ouvido teria todo o seu corpo, fazendo com que ela pecasse. O diabo sabe que, se consegue conquistar o nosso ouvido, todo o nosso corpo se seguirá. (20-04-2005, Madrid)

Nesta perspectiva, a Bíblia pode ser entendida tanto como um objecto de produção de subjectividade e experiência como um objecto de afirmação identitária e contestação política: a escolha de um "tipo" ou versão particular da Bíblia ${ }^{11}$ como elemento diferenciador de outras tradições cristãs, e o uso

10 Refiro-me aqui à relação entre pessoas e objectos (ver, p. ex., Gell 1998; Parkin 1999): a significação e uso atribuídos à Bíblia por parte de crentes cristãos como os da IF invocam uma tradição histórica particular de utilização do texto sagrado - aquilo a que Coleman chamará de narrative emplacement (2000: 119; ver também Engelke 2004).

11 Mais concretamente, as versões contemporâneas da Bíblia de João Ferreira de Almeida (no caso português; primeira edição de 1753) e Reina-Valera (no caso espanhol; primeira edição de 1602) - versões reformadas e traduzidas por protestantes com o objectivo de popularizar a sua leitura, o que não acontecia com a versão Vulgata (latina) oficial da Igreja Católica. 
(leitura, extrapolação, citação) específico da mesma como marcador de uma doutrina particular, são escolhas "políticas" no sentido em que são definidoras de uma identidade religiosa (cristã, protestante, pentecostal, evangélica, etc.) construída, até certo ponto, em oposição com outras identidades religiosas e também com identidades não religiosas.

Recordamos, como exemplo, a forma como os ciganos evangélicos invocam noções de memória e identidade colectivas a partir do texto bíblico, incorporando a agencialidade do Diabo e identificando-se genericamente com as narrativas do Antigo Testamento acerca do êxodo do "povo de Israel", condenado a errar até chegar à "terra prometida" no pacto entre Deus e Abraão - uma narrativa que dialoga com a percepção dos ciganos acerca do seu próprio passado diaspórico e nomádico (ver Gay y Blasco 2002; 2004; Llera Blanes 2006a). Este processo de identificação, presente em livros (memórias, autobiografias) e cânticos (ver Llera Blanes 2006a: caps. II, V), reproduz o mesmo método exegético que observamos nos sermões e discursos públicos dos oradores - método que, de acordo com a tradição literalista evangélica, permite ao leitor/ouvinte estabelecer analogias entre as suas experiências pessoais e as passagens e parábolas bíblicas.

Por outro lado, esta forma de ritual speech (ver Keane 1997; Tambiah 1968) também assenta na pressuposição colectiva - característica da tradição protestante - de que o predicador não é em si o autor, produtor do discurso, mas sim um veículo de transmissão da acção divina; isto implica que (1) o acto cultual, como prática e acção, é um acto comunicacional apoiado num reconhecimento colectivo das intencionalidades que o motivam e das finalidades com ele pretendidas, cujo elemento central é o do contacto com o divino; e (2) essa intencionalidade assenta na ideia de uma "mensagem" (ensinamento, conhecimento) que deve ser transmitida, veiculada, através do orador, pelo Espírito Santo e para os crentes. Neste sentido, o contacto é, igualmente, uma forma de conhecimento. A dinâmica "comentarista" inerente ao processo de leitura e partilha da Bíblia é também uma dinâmica de ensinamento e aprendizagem.

\section{CONFLITO}

Tal como procurei demonstrar na secção anterior, a dinâmica comunicacional da "palavra" assenta claramente numa vertente pedagógica, no sentido de ser uma estratégia de instrução. Neste contexto, na medida em que é pública, partilhada e debatida, é sujeita a escrutínio crítico: é frequente, nos cultos, ouvir sermões em tons acusatórios sobre comportamentos e discursos considerados controversos, ou ouvir, no final dos mesmos, os assistentes comentar (elogiando ou criticando) as prelecções.

Esta dinâmica de conflito pode assumir várias vertentes: por um lado, remetendo para o carácter "estruturante" que tenho defendido para o papel da IF na 
vida dos ciganos portugueses e espanhóis de hoje, não deixa de haver processos de debate e discussão sobre o que é e deve ser "ser cigano" a partir de um ponto de vista cristão evangélico e a partir de uma leitura bíblica - processos a partir dos quais se constroem formas de conhecimento específicas que envolvem noções de história e "cultura". Um ponto aqui apresentado foi o da leitura particular da sua história elaborada pelos ciganos evangélicos; há, no entanto, outros: é frequente, por exemplo, ouvir invocar aspectos da "tradição cigana" (a vingança, a tendência para o embuste) como exemplificadores de comportamentos a rejeitar na exigência ético-moral inerente às noções de conversão e salvação.

Por outro lado, enquanto "comunidade de práticas", a própria dinâmica interaccional entre os próprios crentes é sujeita a "comentário social". Por exemplo, num culto a que assisti em Lisboa em 2004, encontrava-me a assistir a um momento de oração, conduzido pelo candidato local. As luzes estavam apagadas e os crentes, sentados ou de pé, oravam. A dado momento, apercebi-me que o pastor - que se sentara numa bancada lateral ao palco - se tinha levantado e saído para o exterior do local de culto. Momentos depois regressava, desta vez acompanhado por alguns rapazes. O culto prosseguiu até ao momento em que se acenderam as luzes e se iniciou o período do sermão. Aí, o pastor tomou a palavra e proferiu um discurso onde recriminava a atitude de alguns dos frequentadores da igreja pela sua pouca participação nos cultos - dando o exemplo dos rapazes que ele fora encontrar no bar ao lado da igreja, a jogar bilhar - manifestando a sua preocupação pelo futuro da comunidade, já que considerava não existir ali comunhão. Explicou que uma verdadeira igreja era aquela onde os crentes acudiam não "porque sim", mas porque sentiam, honestamente, a vontade de "estar com Deus", recebê-lo através do Espírito Santo. Questionava-se mesmo qual o seu papel perante aquela comunidade em concreto, na medida em que a sua "mensagem" não parecia conseguir passar para os seus interlocutores; propôs, finalmente, um ultimato: se os membros da igreja não se comprometessem plenamente com a "igreja" (aquela em concreto e o movimento em geral), ele trataria de se transferir para outro local.

Neste sentido, a instrução de entendimento ético-moral implica uma dimensão de exigência e dialéctica perante a contradição e o conflito com a doutrina promulgada como sendo hegemónica. Na minha tese propus, a partir da noção do musicólogo Charles Keil de participatory discrepancies, o conceito de "discrepância" para tentar explicar como, em geral, as "coisas" adquirem significado e relevância (tanto individual como social) através da "vitalidade"que lhes é imanente, vitalidade que resulta da dinâmica da interacção social (Keil 2005). Esta noção é, neste sentido, próxima dos argumentos do Victor Turner de The Ritual Process, que propunha exemplos (como o próprio ritual) de acontecimentos como propulsionadores dialécticos do developmental cycle que é a vida social (Turner 1995 [1969]). O seu modelo de liminaridade (como um alheamento 
do socialmente estabelecido) e communitas (como subversor de hierarquias), apesar de frequentemente interpretado como simbolista ou estruturalista, era profundamente defensor da ideia do dinamismo da vida social através da dialética, do processualismo da estrutura (ver Pina Cabral 2000).

Mas, voltando ao conceito de Keil das participatory discrepancies - ou "discrepâncias em participação" -, ele engloba duas noções relevantes em termos de abordagem antropológica de "factos sociais" tais como o que aqui propomos.

Em primeiro lugar, a noção de "participação", que tem vindo a ser explorada recentemente pela antropologia cognitivista e subjectivista no sentido da incorporação (aquisição, desenvolvimento, inscrição corporal) de sentidos e significados através da prática e interacção (ver, por exemplo, Lave \& Wenger 1991). ${ }^{12}$ Em segundo lugar, encontramos a noção de "discrepância", que qualquer dicionário definiria como "divergência" ou "diversidade de opinióes". João de Pina Cabral, na sua análise sobre o "processo social" de negociação de hegemonias e margens, defende a contradição como um aspecto "inapagável" da vida social, um factor positivo na dinâmica de estruturação de relações sociais e culturais (Pina Cabral 2000: 879 e ss.); igualmente, Jean Lave e Etienne Wenger defendem que os processos de aprendizagem e participação se desenvolvem necessariamente a partir da multiplicidade e diversidade de pontos de vista (1991: 113 e ss.).

Em terceiro lugar, o interesse deste conceito releva precisamente da interacção entre ambas as noções, ou seja, da ideia de que a discrepância entre elementos (sejam eles quais forem) participa na acção em si, que ganha corpo e agencialidade precisamente através dessa interacção ou dialéctica. Na perspectiva que pretendo aqui desenvolver, essa dialéctica remete para a permanente fricção entre múltiplas e distintas formas de acção social. Isto implica, portanto, que fenómenos sociais - ou seja, as acções ou acontecimentos que são socialmente relevantes para um grupo indeterminado de pessoas - como os actos cultuais estão em permanente estado incompleto (imperfeito), estão socialmente inseridos e são invariavelmente complexos nessa inserção. Por outro lado, também dão azo a conjuntos de significados socialmente estruturantes.

Nesta linha, o ensino, a endoutrinação e a aprendizagem presentes nos sermões da IF são igualmente momentos de debate e oposição. Reproduzo aqui um excerto de uma pregação a que assisti em Madrid, apresentada por um dos principais predicadores daquela região:

[...] Há pessoas que não sabem aquilo que aprovam. Porquê? Por falta de conhecimento. Por exemplo, há instantes vocês [dirige-se ao coro] cantaram um "corinho" que é cantado em todas as igrejas. E não é nosso, das nossas 
igrejas ciganas, é de um adorador internacional, não de um artista qualquer de qualquer lado. É de um adorador internacional que revolucionou o louvor em toda a América Latina [refere-se a M.W.]. No entanto, ele comete nesse cântico um erro doutrinal importante, que é o de dizer "minguar... para que cresças tu...". [Canta] "Minguar... para que cresças tu...". Isto é um erro doutrinal. Ninguém pode minguar para que ELE cresça. Tem que ser ELE a crescer para que NÓs minguemos. Porquê? Porque "minguar para que cresças tu" é a coluna vertebral do legalismo, ${ }^{13}$ vem das entranhas do legalismo, e estranho que um homem deste calibre cometa um erro destes. [...] Como é que eu vou pecar se não cresci? Como deixarei eu de querer o demónio e as trevas se não cresci primeiro? Há apenas uma maneira de eu deixar de amar o pecado, de querer o pecado, que é quando Cristo vem para mim. Mas eu não posso minguar sem que ElE cresça antes. Assim, o texto não seria "minguar para que cresças Tu”, mas sim "minguar QUANDO cresças tu". [...] Porque a ordem bíblica, tomando esse versículo [João 3:30-31], diz-se "Convém que ele cresça e eu mingue". É esta a ordem. Porque quem quer ser cristão pelas suas próprias forças não vai conseguir. [...] Aqui há apenas uma maneira de viver a vida cristã, que é através do poder do Espírito Santo, pela obra do Espírito Santo. (Madrid, 12-04-2005)

Este tipo de argumentação é frequente nos sermões bíblicos: a colocação de um "problema social" e sua discussão teórica em função da exegese ou extrapolação bíblica, tendo em vista um ensinamento moral. Neste caso concreto, o predicador manifestava a sua preocupação perante o excesso de protagonismo que alguns músicos cristãos evangélicos estavam a assumir, no âmbito da "música cristã contemporânea", na veiculação de conhecimento teológico. Para ele, estes músicos não teriam a formação necessária para poder oferecer ensinamentos dessa índole, constituindo mesmo (apesar de inconscientemente) uma ameaça à instauração do "verdadeiro comportamento cristão". Esta reflexão remete para um longo debate existente nos meios cristãos e evangélicos acerca do papel da música e dos músicos nas igrejas contemporâneas, um debate marcado por duas posições discrepantes em relação a esse papel: se, por um lado, uns defendem que essa música (e o mercado gerado à sua volta) é uma forma encontrada por Deus para comunicar com a juventude no contexto moderno e globalizado de hoje, outros a acusarão como a "obra de Satanás" nas igrejas de hoje, corrompendo a lógica inicial de adoração e instaurando uma ordem mercantilista e vã. ${ }^{14}$

13 O "legalismo" é entendido, nos meios cristãos, como a defesa de leis, regras e prescrições como forma de santificação e culto. Neste sentido, opõe-se à ideia de "graça” como formas de cumprimento do louvor. A IF, como igreja pentecostal carismática, é anti-legalista. Ver, por exemplo, Douglas (1999) para uma aproximação a este tema.

14 Ver, para este debate, Llera Blanes (2006: cap. VI). 
Como referi no início desta secção, sermões como o que acima reproduzi não só oferecem comentário público como estão igualmente sujeitos ao mesmo. Uma vez finalizado o sermão, o pastor da igreja local tomará o microfone para fazer um balanço das principais mensagens que os presentes deveriam reter do culto que ali termina. Pedirá ainda a um membro da igreja que faça uma oração de despedida; finalmente, é tocado um último cântico que acompanhará a "oferta" do dízimo. À saída, é retomada a conversa informal entre os presentes. Muitos comentarão os discursos anteriormente veiculados. Nessa noite de Madrid, por exemplo, alguns manifestavam o seu desacordo com a posição "demasiado doutrinal" do predicador - acreditando que não se devia levar as letras musicais tão literalmente.

\section{CONCLUSÃO}

Ao longo das últimas páginas, procurei elaborar, simultaneamente, um exercício descritivo de uma dinâmica ritual concreta (os cultos na IF) e uma proposta teórica de compreensão dos mesmos através dos conceitos de "contacto", "conhecimento" e "conflito". Estes conceitos serviriam, portanto, como instrumentos interpretativos para compreender o lugar que os cultos ocupam nos espaços sociais dos ciganos portugueses e espanhóis de hoje, nomeadamente daqueles que aderiram a um movimento evangélico como a IF. Enquanto movimento religioso cristão minoritário nos planos nacionais português e espanhol, a IF tornou-se num agente religioso maioritário nos quotidianos ciganos, não só porque ocupou espaços físicos e mentais no seio desses quotidianos, como também porque ofereceu uma leitura alternativa dos conceitos de identidade, memória e história cigana - leitura que ocupa, hoje, um estatuto de competidor com noções laicas de ciganidade como minoria étnica sujeita a exclusão social (ver Gay y Blasco 2002), oferecendo respostas concretas para os dilemas da modernidade cigana na Península Ibérica, tendo como elemento chave a causalidade divina da experiência étnica cigana. Neste sentido, a noção de "salvação" inerente à proposta doutrinal evangélica reconfigura, com acções concretas (as referidas políticas de proximidade, a sociabilidade cristã, os projectos colectivos, a visão do mundo universal, etc.) as dificuldades por trás das tradições de homogeneização cultural e reclusão social do cigano. A "crise social" do cigano ibérico da segunda metade do século XX - criminalização, adição, desemprego, desenraizamento socioespacial, etc. - pôs em causa dinâmicas históricas relativamente consensuais: a "endo" ou homogamia matrimonial, patrilinhagem, autoridade tradicional, "lei cigana", etc., foram questionadas no processo de mudança estrutural então verificado (San Román 1997). Se o activismo sociopolítico "Rom" foi uma tentativa de superação dessa crise social, a IF mostrou um caminho alternativo assente noutros pressupostos: determinismo, agencialidade divina, autoridade bíblica. 
Por outro lado, a própria doutrina religiosa pentecostal carismática assume como eixo central uma dialéctica entre o carácter experiencial e o carácter definitório da crença: é através da manifestação e sensação corporal do divino que se constroem e partilham lógicas comunicacionais. Mais do que verificar, como defende Bloch, uma desconexão entre sistemas de comunicação ritual e não ritual (1989 [1979]), percebemos aqui como as dinâmicas de contacto, conhecimento e conflito constituem mecanismos de transporte entre o espaço do culto e os espaços (sociais, representacionais, temporais) que o rodeiam.

A confluência dos pontos anteriores tornará o "acto cultual" precisamente no acto que confere coerência e sentido à opção religiosa dos crentes: porque materializa, num conjunto de práticas colectivas, uma ordem ideológica (doutrina, visão do mundo); porque permite aos crentes, enquanto "comunidade de práticas”, transformar essa ordem ideológica numa ordem de práticas concreta de carácter generativo - no sentido em que é capaz de produzir e reconfigurar significados e ideias. Noutras palavras, glosando James Fernandez, enquanto ritual, o acto cultual oferece consistência, gratificação, individuação e instrumentalização aos que nele participam (Fernandez 1966), ligando a escala de representações do passado, presente e futuro.

\section{BIBLIOGRAFIA}

ALMEIDA, Miguel Vale de, 1996, "Corpo presente", em Miguel Vale de Almeida (org.), Corpo Presente. Treze Reflexões Antropológicas sobre o Corpo. Oeiras, Celta, pp. 1-22.

ASAD, Talal, 1993, Genealogies of Religion. Discipline and Reasons of Power in Christianity and Islam. Londres e Baltimore, Johns Hopkins University Press.

AUSTIN, John, 2005 [1962], How to Do Things with Words. Harvard, Harvard University Press (2. ${ }^{\mathrm{a}}$ edição).

BELL, Catherine, 1997, Ritual. Perspectives and Dimensions. Oxford, Oxford University Press. BLOCH, Maurice, 1986, From Blessing to Violence. History and Ideology in the Circumcision Ritual of the Merina of Madagascar. Cambridge, Cambridge University Press.

—, 1989 [1979], Ritual, History and Power: Selected Papers in Anthropology. Londres, Athlone Press.

BORDIGONI, Marc, 2002, "Le 'pélerinage des gitans', entre foi, tradition et tourisme", Ethnologie Française, 32 (3): 489-501.

Bourdieu, Pierre, 2002, Esboço de uma Teoria da Prática. Precedido de Três Estudos de Etnologia Cabila. Oeiras, Celta.

CANTÓN DELGADO, Manuela, 2001, "Gitanos protestantes. El movimiento religioso de las Iglesias 'Filadelfia' en Andalucía, España”, Alteridades, 11 (22): 59-74. 
CANTÓN DELGADO, Manuela, 2002, "La construcción social de la sospecha. Minorías religiosas contemporáneas y procesos de exclusión”, Estudios sobre las Culturas Contemporáneas, VIII (15): 89-111.

CANTÓN Delgado, Manuela, et al., 2004, Gitanos Pentecostales. Una Mirada Antropológica a la Iglesia Filadelfia en Andalucía. Sevilla, Signatura Deimos.

COElho, Adolfo, 1995 [1892], Os Ciganos de Portugal, Com um Estudo sobre o Calão. Lisboa, Dom Quixote.

COLEMAN, Simon, 2000, The Globalisation of Charismatic Christianity. Spreading the Gospel of Prosperity. Cambridge, Cambridge University Press.

COMAROFF, John, e Jean Comaroff, 1991, Of Revelation and Revolution, Volume 1: Christianity, Colonialism, and Consciousness in South Africa. Chicago, University of Chicago Press.

COSTA, Joaquim, 2006, Sociologia dos Novos Movimentos Eclesiais. Focolares, Carismáticos e Neo-catecumenais em Braga. Porto, Afrontamento.

CRAPANZANO, Vincent, 2000, Serving the Word. Literalism in America: from the Pulpit to the Bench. Nova Iorque.

CSORDAS, Thomas J., 1997, Language, Charisma, and Creativity. The Ritual Life of a Religious Movement. Berkeley, Los Angeles e Londres, University of California Press.

DOUGLAS, Mary, 1999, Leviticus as Literature. Oxford, Oxford University Press.

DURKHEIM, Émile, 2002 [1912], As Formas Elementares da Vida Religiosa. O Sistema Totémico na Austrália. Oeiras, Celta.

ENGELKE, Matthew, 2004, “Text and performance in an african church: the book, 'Live and Direct'”, American Ethnologist, 31 (1): 76-91.

FERNANDEZ, James, 1966, "Unbelievably subtle words: representation and integration in the sermons of an african reformative cult", History of Religions, 6 (1): 43-69.

GAY Y BLASCO, Paloma, 2000, "The politics of evangelism. Hierarchy, masculinity and religious conversion among the gitanos", Romani Studies, 10: 1-22.

— 2001, “We don't know our descent': How the gitanos of Jarana manage the past", Journal of the RAI (N.S.), 7: 631-647.

—, 2002 , "Gipsy-roma diasporas. A comparative perspective", Social Anthropology, 10 (2): 173-189.

— 2004, "Evangelical transformations of forgetting and remembering: The politics of gitano life”, em Frances Pine, Deema Kaneff, e Haidis Haukanes (eds.), Memory, Politics and Religion. The Past Meets the Present in Europe. Münster, Lit Verlag.

GELL, Alfred, 1998, Art and Agency: An Anthropological Theory. Oxford (US), Oxford Univ. Press. HARDING, Susan, 2000, The Book of Jerry Falwell. Fundamentalist Language and Politics. Princeton, NJ, Princeton University Press.

JUleS-ROSETTE, Bennetta, 1975, African Apostles. Ritual and Conversion in the Church of John Maranke. Ithaca e Londres, Cornell University Press.

KEANE, Webb, 1997, "Religious language", Annual Review of Anthropology, 26: 47-71.

—, 2002, “Sincerity, 'modernity' and the protestants”, Cultural Anthropology, 17 (1): 65-92.

KEIL, Charles, 2005, "Participatory discrepancies and the power of music", em Charles Keil, e Steven Feld, Music Grooves. Tucson, AR, Fenestra Books, 96-108.

LAGUNA ÁRIAS, David, 2005, Los Tres Cromosomas. Modernidad, Identidad y Parentesco entre los Gitanos Catalanes. Granada, Editorial Comares.

LAMBEK, Michael, 2002, The Weight of the Past. Living with History in Mahajanga, Madagascar. Nova Iorque, Palgrave MacMillan. 
LAVE, Jean, e Etienne Wenger, 1991, Situated Learning. Legitimate Peripheral Participation. Cambridge, Cambridge University Press.

LE COSSEC, Clément, 1985, “Phénomène pentecôtiste' ou réveil religieux?”, Études Tsiganes, 1: 19-21.

— 2003 [1991], Mi Aventura entre los Gitanos. Sabadell, RTV Amistad.

LIÉGEOIS, Jean Pierre, 1989 [1985], Ciganos e Itinerantes. Lisboa, Santa Casa da Misericórdia.

LLERA BLANES, Ruy, 2003, "Nascer no culto: Modalidades de acesso ao movimento evangélico cigano em Portugal”, Religião e Sociedade, 23 (1): 107-131.

—_, 2006a, Aleluia! Música e Identidade num Movimento Evangélico Cigano na Península Ibérica, tese de doutoramento em Antropologia, Instituto de Ciências Sociais, Universidade de Lisboa.

—, 2006b, "The atheist anthropologist. Believers and non-believers in anthropological fieldwork", Social Anthropology, 14 (2): 223-234.

LOPES, Daniel Seabra, 2006, "Mercados encobertos. Os ciganos de Lisboa e a venda ambulante”, Etnográfica, 10, (2): 319-333.

MAFrA, Clara, 2002a, Na Posse da Palavra. Religião, Conversão e Liberdade Pessoal em Dois Contextos Nacionais. Lisboa, Imprensa de Ciências Sociais.

— brasileiros e portugueses", Mana, 6 (1): 57-86.

MAYALL, David, 2004, Gypsy Identities 1500-2000. From Egypcians and Moon-men to the Ethnic Romany. Londres e Nova Iorque, Routledge.

MÉNDEZ LÓPEZ, Carmen, 2006, "Por el camino de la participación. Una aproximación contrastada a los procesos de integración social y política de los gitanos y las gitanas", tese de doutoramento, Universitat Autònoma de Barcelona

MEYER, Birgit, 2004, “'Praise the Lord': Popular cinema and pentecostalite style in Ghana's new public sphere”, American Ethnologist, 31 (1): 92-1 10.

PARKIN, David, 1991, "Mementoes as transitional objects in human displacement", Journal of Material Culture, 4 (3): 303-320.

PASQUALINO, Caterina, 2002, "Politique, catholicisme et évangélisme: Les gitans d'Estrémadure (Espagne)", Gradhiva, 32: 37-52.

PELS, Peter, 1999, A Politics of Presence: Contacts Between Missionaries and Waluguru in Late Colonial Tanganyika. Londres e Nova Iorque, Routledge.

PINA CABRAL, João de, 2000, "A difusão do limiar: Margens, hegemonias e contradições", Análise Social, 153: 865-892.

RODRIGUES, Donizete, e Ana Paula Santos, 2004, “O movimento pentecostal cigano: O caso da Igreja Evangélica de Filadélfia de Portugal”, em Donizete Rodrigues (org.), Em Nome de Deus. A Religião na Sociedade Contemporânea. Porto, Afrontamento.

SAN ROMÁN, Teresa (ed.), 1986, Entre la Marginación y el Racismo: Reflexiones sobre la Vida de los Gitanos. Madrid, Alianza.

—, 1997, La Diferencia Inquietante. Viejas y Nuevas Estrategias Culturales de los Gitanos. Madrid, Siglo XXI.

STromberg, Peter, 1993, Language and Self-transformation. A Study of the Christian Conversion Narrative. Cambridge, Cambridge University Press.

SWICK, Dennis, 1999, Estadísticas de España. Madrid, Decisión.

TAMBIAH, Stanley, 1968, “The magical power of words”, Man (N. S.), 3 (2): 175-208. 
TAUSSIG, Michael, 1991, “Tactility and distraction”, Cultural Anthropology, 6: 147-153.

TURNER, Victor, 1995 [1969], The Ritual Process: Structure and Anti-Structure. Nova Iorque, Aldine.

—, 1996 [1957], Schism and Continuity in an African Society. A Study of Ndembu Village Life. Oxford, Berg.

VAlverde, Paulo, 2000, Máscara, Mato e Morte. Textos para uma Etnografia de São Tomé. Oeiras, Celta [compilação e prefácio de João de Pina Cabral].

VILAÇA, Helena, 2006, Da Torre de Babel às Terras Prometidas. Pluralismo Religioso em Portugal. Porto, Afrontamento.

WHITEHOUSE, Harvey, 2004, Modes of Religiosity. A Cognitive Theory of Religious Transmission. Walnut Creek, Altamira Press.

WILLIAMS, Patrick, 1984, "Pour une approche du phénomène pentecôtiste chez les tsiganes”, Études Tsiganes, 30 (2) : 49-51.

— messianique, stéréotypes et affirmation d'identité”, em AA. VV., Vers des Societés Pluriculturelles: Études Comparatives et Situation en France, Actes du Colloque International de l'AFA. Paris, Éditions de l'ORSTOM.

\section{Contact, knowledge and conflict. Social and cultual dynamics in an evangelical gypsy movement in the Iberian Peninsula}

Ruy Llera Blanes

Instituto de Ciências Sociais da Universidade de Lisboa

ruy.blanes@ics.ul.pt

This article proposes an analysis of the evangelical cults of the Filadelfia Church - a Christian Protestant movement created among Portuguese and Spanish Gypsy communities. In order to attempt an understanding of the role played by ritual praxis within religious and identitary experience, I propose the notions of "contact", "knowledge" and "conflict" as explanatory devices for the local and social implantation of the cults within Gypsy contemporariness, connecting ideology, memory and practices.

KEYWORDS: Gypsies, evangelical cult, ritual, religious language, contact, Iberian Peninsula. 